\title{
The role of systems modeling in drug discovery and predictive health
}

\author{
Eberhard O Voit \\ From 5th German Conference on Cheminformatics: 23. CIC-Workshop \\ Goslar, Germany. 8-10 November 2009
}

Systems biology is the result of a confluence of recent advances in molecular biology, engineering, and the computational sciences. It can loosely be categorized into experimental and computational systems biology. Experimental high-throughput methods, assisted by robotics, image analysis, and bioinformatics, have been used in the drug industry for quite a while, and current screening tests for drug efficacy and toxicity regularly involve genomic, proteomic, and molecular modeling approaches. By contrast, the role of computational methods of biological systems analysis is still emerging. This presentation focuses on computational systems modeling and its increasingly important role at several junctures of the drug development pipeline. Examples to be discussed include mathematical models for receptor dynamics, pharmacokinetics, and metabolic and signaling pathway analysis. In the context of the latter, Biochemical Systems Theory is proposed as a highly advantageous default framework for model design, diagnostics, manipulation, and system optimization. The development of dynamic models for complex disease processes permits the straightforward inclusion of methods for custom-tailoring models, which is a key step toward personalized medicine and predictive health [1-5].

\section{Published: 4 May 2010}

\section{References}

1. Voit EO: Computational Analysis of Biochemical Systems. A Practical Guide for Biochemists and Molecular Biologists Cambridge University Press, Cambridge, UK 2000, xii + 530

2. Voit EO: Metabolic modeling: A tool of drug discovery in the postgenomic era. Drug Discovery Today 2002, 7(11):621-628.

Correspondence: eberhard.voit@bme.gatech.edu Integrative BioSystems Institute and Wallace H. Coulter Department of Biomedical Engineering, Georgia Institute of Technology, 313 Ferst Drive, Atlanta, GA 30332-0535, USA
3. Voit EO: The dawn of a new era of metabolic systems analysis. Drug Discovery Today BioSilico 2004, 2(5):182-189.

4. Voit EO, Brigham KL: The role of systems biology in predictive health and personalized medicine. The Open Path. J 2008, 2:68-70.

5. Voit EO: A systems-theoretical framework for health and disease. Math Biosc 2009, 217:11-18.

doi:10.1186/1758-2946-2-S1-O2

Cite this article as: Voit: The role of systems modeling in drug discovery and predictive health. Journal of Cheminformatics 2010 2(Suppl 1):O2.

\section{Publish with ChemistryCentral and every scientist can read your work free of charge \\ "Open access provides opportunities to our colleagues in other parts of the globe, by allowing anyone to view the content free of charge." W. Jeffery Hurst, The Hershey Company. \\ - available free of charge to the entire scientific community \\ - peer reviewed and published immediately upon acceptance \\ - cited in PubMed and archived on PubMed Central \\ - yours - you keep the copyright \\ Submit your manuscript here: \\ http://www.chemistrycentral.com/manuscript/

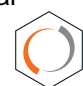 Chemistry Central}

